\title{
Mucosal Melanoma of the Head and Neck pN0 TNM Finding v7
}

National Cancer Institute

\section{Source}

National Cancer Institute. Mucosal Melanoma of the Head and NeckpNO TNM Finding v7. NCI Thesaurus. Code C89137.

Mucosal melanoma of the head and neck with no metastases to regional lymph nodes.

(from AJCC 7th Ed.) 